\title{
'Glocal' and integrated churches within a practical theological imagination of 'home away from home': towards a ministry of migrants and refugees in diaspora
}

\author{
Magezi, Vhumani \\ North-West University \\ vhumani@hotmail.com
}

\begin{abstract}
Migration has become a major global challenge in recent years. Host countries' responses to migrants are varied - some accommodate and integrate migrants, others are apathetic, and migrants face exclusion and violent rejection. This suggests that host countries have developed mechanisms to cope with the challenges posed by migrants. Migrants have also developed systems to mitigate the impact of the challenges they encounter, such as the establishment of churches in their host countries. These churches may be referred to as 'glocal churches'. In view of this, this article considers a practical theological imagination of 'home away from home' as a migrant-theological and ministry-informing approach and draws on the theological notion that all humans are foreigners (or migrants - homo viator) in whichever life spaces they exist. This study argues that this approach provides a crucial nexus and challenge for church ministry integration in contexts of migration and challenges countries to be hospitable based on Imago Dei (theology) and human dignity (human rights) principles. It is argued that maintained Imago Dei and human dignity provide a critical link between churches and a nation. Furthermore, the notions of 'inclusiveness' for host people and 'home away from final eschatological home' for migrants provide a practical theological imagination that challenge a host country's citizens to positively consider migrants and migrants to avoid self-exclusion practices and establish integrated churches and communities.
\end{abstract}

Key words

Migrants and refugees; theology of migration; theological imagination; 'glocal' churches; practical theology of home 


\section{Problem statement and background}

Migration has been rising in recent years (Skeldon 2013; Gilmore 2016; McAdam 2014; Gannon 2001; Martin, Weerasinghe and Taylor 2014; UNHCR 2015). In 2010, the total South-to-North and South-to-South migration was $34 \%$ each, North-to-South was $6 \%$, and North-to-North was 26\% (UN Department of Economic and Social Affairs 2010). The number of international migrants increased from 214 million in 2010 to 232 million in 2013 (UN Department of Economic and Social Affairs 2013). According to UNHRC (2015:1):

The number of international migrants worldwide has continued to grow rapidly over the past fifteen years reaching 244 million in 2015, up from 222 million in 2010 and 173 million in 2000. Nearly two thirds of all international migrants live in Europe (76 million) or Asia (75 million). Northern America hosted the third largest number of international migrants (54 million), followed by Africa ( 21 million), Latin America and the Caribbean (9 million) and Oceania (8 million). In 2014, the total number of refugees in the world was estimated at 19.5 million. Turkey became the largest refugee-hosting country worldwide, with 1.6 million refugees, followed by Pakistan (1.5 million), Lebanon (1.2 million), and the Islamic Republic of Iran (1.0 million). More than half (53 per cent) of all refugees worldwide came from just three countries namely, the Syrian Arab Republic (3.9 million), Afghanistan (2.6 million), and Somalia (1.1 million).

In an overview of global migration trends, the International Organization for Migration (IMO) (2014:1) paints a vivid picture of migration by stating that "approximately one in seven people is migrating every day.

Despite the reality of migration, migrants experience many challenges including restrictive and onerous visa requirements, very little protection, limited access to regular entry channels, exploitation as a result of poor control of asylum seekers, exclusion in the workforce, poor integration with host communities, and many more (Hastings Borough Council 2015; Nuñez 2014; Statistics Canada 2005; Gilmore 2016; Datta, McIlwaine, Evans, Herbert, May and Wills 2006; Sutherland 2014). Notably, host countries' responses to migrants have been diverse, and range from accommodation and integration to apathy, exclusion and violent rejection. Migrants in 
South Africa, for example, experienced extremely violent xenophobic attacks in 2008 and 2015. Oluoch (2012) observed that discrimination against migrants is rife in the US. It is critical to note that host countries' responses to migrants may not necessarily be deliberately inhumane acts but are rather an indication of the struggle to embrace foreign people, who are different. This may be an indicator of the (lack of) mechanisms in host countries to cope with foreign people.

Migrants have developed systems to mitigate the impact of the challenges they encounter. Some of these include the formation of separate communities and foreign churches, or 'glocal churches'. Members of these churches are migrants who originate from the same country. As such, they use their native language during church services, and church activities resemble those of their country of origin. These churches provide spaces where migrants can feel that they are at 'home while away from home', and provide opportunities where migrants can support one another in issues that they may encounter. Hirschman (2003:6) observed that religious beliefs and practices serve as ballast for migrants as they struggle to adapt to life in their new country. However, religion cannot be considered from a spiritual dimension alone. Hirschman (2003:22) acknowledging Min's (1992) report, noted that some Korean ethnic churches in New York City offer language classes (both Korean and English), a full Korean lunch after services, and seminars on practical as well as spiritual topics. Migrant ethnic churches make major efforts to serve the social and economic needs of their congregants, and provide information on housing and various social and economic opportunities. There are, therefore, many social and economic benefits to joining churches. Religion can maintain a community as well as offer it continuity (Hirschman 2003:25).

Migration is a central issue for the church and theology. According to Schär and Geisler (2008:4), the concepts of salvation in the Bible are "migrationbearing", starting with the promise to Abraham, and continuing with the

1 'Glocal churches' is a term that has been coined from glocalisation. Glocalisation expresses the way globalisation dynamics are represented locally, leading to an interpenetration of the local and global scales that create context-dependent outcomes. Some authors go so far as to suggest that glocalisation is the way that globalisation really operates (Robertson, 1992; Swyngedouw, 2004). Members of glocal churches are part of the integrated global world where migrants have settled and yet, in some respects, act and associate like people in their country of origin. 
exodus right down to the Babylonian exile. Groody (2009) added that the theme of migration is at the heart of the Judeo-Christian scriptures. From the call of Abraham to the exodus from Egypt and Israel's wandering in the desert and later exile, migration has been part of the history of salvation. From Jesus' birth, understood as the movement of God into this alien world, to His resurrection and return to the Father, and from the holy family's flight into Egypt to the missionary activity of the church, the very identity of the people of God is intertwined with the story of movement, risk and hospitality.

Migration is a core theme of theology and the church (Schär and Geisler 2008), giving rise to the following questions: Can a theological and ministerial approach be used to help host countries and migrants integrate and co-exist effectively? What practical theological approach should be formulated to ensure effective ministry within migration situations? In response to these questions, a practical theological imagination of 'home away from home' is proposed. The theological notion that all humanity are foreigners in whichever life spaces they exist provides a crucial nexus and challenge for integration in contexts of migration. Such an approach challenges both the local/host country's citizens to consider migrants positively, and migrants to avoid self-exclusion. This theological and practical theological approach provides opportunities for constructive engagement on churches that reflect the diversity of the ideal, integrated church that contributes to overcoming the challenges posed by migration.

\section{Embracing migrants - host nations' dilemma and migrants' coping strategies}

Globalisation has made it much easier for people to migrate, but it has also exposed the dark side of migrants' lives in receiving countries. Yaghmaian (in Vick 2015:31) observed the following: 'Because of globalisation, you have awareness of life elsewhere in the world. So you move.' You move in pursuit of happiness, prosperity and wealth. However, as people try to enter foreign countries, they encounter harsh immigration laws, hard living conditions and sometimes experience painful rejection (Gilmore 2016; Datta et al. 2006; Sutherland 2014). When migrants' (and especially refugees') hopes are dashed activists, civic groups and the United Nations criticise host nations and label them as heartless. For instance, Human 
Rights Watch (2015) reported that after Kenya experienced many killings linked to Somali refugees, the government tightened its security, resulting in a global outcry. In trying to be hospitable, the country ended up being demonised. Globalisation is thus a double-edged sword.

Louw (2016) citing National Geographic Magazine (2008), warned against the possible devastating effects of migration on local communities. Migration results in cultural dilution - with recorded complaints of this cultural dilution within host nations (Tan 2012; Thomsen 2016). Accepting and integrating migrants, particularly refugees, also costs an enormous amount of money, adding strain to host nations' resources. Nie (2015) noted that it costs about $\$ 119,000$ to settle one refugee in Germany. When this amount is multiplied against the number of refuges entering a country, it is not surprising that host nations are concerned. Metcalfe-Hough (2015) indicated that in 2015 over 590,000 refugees arrived in Europe by sea more than twice the number of refugees that reached Europe by sea in 2014. Almost 630,000 new asylum claims were made in 2014 compared to just over 430,000 in 2013. Host nations bear these high costs, often at the expense of national development. A further cost-related challenge is the expectation that host nations will support refugees in their countries of origin or in neighbouring countries (Richard 2014).

While migrants do make notable contributions to the economies of host nations through labour, they also contribute to unemployment. Even though migrants tend to work in low-skilled jobs, they are often viewed as competitors by their host communities (Nie 2015; Garson \& Loizillon 2003; Karakas 2015). The dilemma for host countries is looking after citizens and migrants fairly. Another dilemma posed by migrants, particularly refugees, is that their opponents tend to follow them to host countries. By providing refuge and safety to refugees fleeing persecution and wars, host nations expose their own citizens to possible attacks. For instance, Syrian rockets threaten the Turkish town of Kilis, which provides safety to Syrian refugees, exposing the nation to external attack and placing Turkish civilian lives in danger (Pakoz 2016). A further challenge posed by migrants, and in particular refugees, is the perceived link between refugees and terrorism. Plucinska (2015), Louw (2016) and Faulconbridge and Young (2015) observed that the Paris Massacre triggered varying responses to migrants in France. Louw (2016) added that the link between 
migrants (refugees) and terrorism was strengthened by the fact that one of the gunmen who died in the Paris attacks was the holder of a Syrian passport and was registered as a refugee in several European countries.

These challenges demonstrate the complexities of migration, and explain the increasing apathy towards migrants. In response to these challenges, host nations have intensified restrictive measures, introduced harsh migration laws and border controls and increased their focus on their citizens. According to Vick (2015:34) 'the limits of compassion, coupled with wariness of Muslims, comes into remorseless focus, even in an immigrant nation'. Louw (2016) rightly summarised the situation as a crisis that has drained emotional resources, become a financial and economic burden, heightened global xenophobia and lead to a spiritual crisis of values and compassion. In such a situation, new ways of coping and viewing life need to be explored, but the question of how migrants respond in this situation arises.

Because of these challenges, refugees and migrants have to find ways to survive and cope with life in their host countries. Some migrants have adopted destructive responses while others have sought to co-exist with the citizens of their host nations and explore possibilities and opportunities for survival. Walt (2015:9) cited the following as a destructive response: 'Some young French Muslims, disillusioned by the economic hardship and what they see as a French population increasingly hostile to outsiders, have looked abroad for direction and meaning, to the jihadist groups fighting Syria and Iraq.' On the other hand, many migrants have developed coping strategies for the challenges that they face in their host countries. These challenges include language barriers, labour discrimination, insecurity, limited protection, negative perception, harsh laws, a lack of home and family support structures, and exclusion (Martin 2013; UNHRC 2016; Sutherland 2014; Bose 2014:23; Chelius 2014; Albuja 2014; Gannon 2001).

One coping mechanism is the establishment of social networks with fellow migrants (Thomas 2010; Willems 2005) through which information on many issues is shared (Datta et al. 2006:17). Another critical coping resource for migrants is religious communities, particularly churches. Hirschman (2005:6) observed that religious beliefs and practices could serve as ballast for migrants as they struggle to adapt to their new countries. Herberg (1960:12) stated that migrants are confronted with the 
existential question of 'Who am I?' In a new social context, migrants often find meaning and identity in reaffirming traditional beliefs, including the structures of faith that may have been taken for granted before. Migrant and ethnic churches make every effort to serve the social and economic needs of their congregants, and provide information on housing and various social and economic opportunities (Hirschman 2003). Ethnic churches therefore provide a sense of belonging, security, identity, revitalizing the culture of origin, and providing migrants with opportunities to socialise with people from different cultural backgrounds under the umbrella of a common religion (Adogame 2013:494-498). Adogame (2013:507) added that these ethnic churches fill a spiritual vacuum and offer a 'home away from home' for many disenchanted migrants and become places where people feel important and valued. In addition, irrespective of members' cultural backgrounds, a sense of belonging and community is rekindled in the church through this religious and ethnic identity.

As observed above, the search for access to resources, emotional support, and social networks, and finding a feeling of ethnic home interplay to sustain ethnic and migrant churches, or 'glocal churches'. Members of these churches are part of the integrated global world where they have settled, and yet, they act like and associate with people from their native country. The questions that emerge from this situation are: Is the role that migrant churches play appropriate? Should churches be used as separate enclaves to advance the social networks of particular communities, and exclude others? How could the pathology of exclusion in some host nation communities and churches be shifted to build integrated, inclusive communities and churches?

\section{Towards a theology of home and church within the complexity of migration for integrated ecclesiology}

Louw (2016) citing Polak (2014) stated that human beings (homo sapiens) are in essence homo migrans. Throughout history, people have been on the move. One can therefore argue that migration is a social phenomenon and part of human existence (Castles \& Miller 2009:299). Modern migration is about a new mode of defining identity, and diversification within mass pluralisation. This challenges our understanding of national states. If people are always on the move, then both migrants and host communities 
are in a state of temporariness. This raises questions on very essence of what it means to be a church, and why churches even exist. Is the practice of church enclaves by migrants or exclusive churches by some host countries consistent with the mission and purpose of the church?

These questions are critical for an operative ecclesiology in a global world where migration is a permanent feature (Yves Congar in Bergson 2015). An operative ecclesiology refers to the performative actions of the church within concrete contexts. It reflects on ecclesial matters not merely from the viewpoint of denominational traditions and dogmatic confessions, but within communal life systems. At the heart of an operative ecclesiology is the following question: What does it mean to be a church in my context? Within the context of migrant and host nation churches in our global world, where people are constantly on the move, the question arises: How should church be done and practiced in order to reflect the multi-coloured face that it portrays - every people, language, and tongue (Revelation 7:9)? What theology can be formulated to challenge both migrants and host nations to reassess their views of the church and being Christians in order to change society?

Migration is deeply theological. Christian foundational doctrines draw significantly on the notion of migration. The Lausanne Movement (2004) formulated a theological position hinging on the notion that all humans are migrants, starting with Adam and continuing to us (The Lausanne Occasional Paper 2004). The Lausanne Movement (2004) stated that Adam (the forefather of all humanity) migrated in God's judgment. He migrated from the Garden of Eden to God because of his disobedience. Abraham migrated in the form of God's promise/blessing to inherit the promised land of Canaan. Abraham's migration was central in reversing the Adamic migration, which was destined for destruction. In the form of judgment, the Israelites migrated to Egypt and, in the form of blessing and forgiveness, migrated back to the promised land of Canaan. Joseph migrated to Egypt. Migration is therefore a pervasive theme in the Old Testament. In addition, Theological Reflection on Migration (2008) stated that the theme of migration is integrated in the Old and New Testaments. In this work, and showed that the concepts of salvation in the Bible are 'migration bearing', beginning with the promise to Abraham, continuing with the exodus experience and the Babylonian exile (Theological Reflection on Migration 2008:4). Similarly, Groody (2009) added that because the 
theme of migration is at the heart of the Judeo-Christian scriptures, the very identity of the people of God is inextricably intertwined with the story of movement, risk and hospitality.

In applying the biblical injunction and model of migration to the church, the church as God's representative and agency of change in the world should model the way to respond to the migration crisis. The church has the God-given responsibility of spreading the gospel and putting the message of God into action. The church is expected to defend those who are marginalised, including migrants (World Council of Churches 2014). It is argued that the church should seek justice and mercy for the oppressed, and is called upon to defend those whose God-given rights are not respected. The church should be vocal on these issues and should enter into the migration debate to help create a migration system that is fair and just for all. In this regard, the church should contribute to the debate by considering migration from God's perspective and, in particular, how God expects hosting nations to treat migrants. However, in saying this, the church of Christ is not encouraging irregular migration. Instead, it is modelling and championing the biblical principles of compassion, love and hospitality towards foreigners, whilst urging migrants to respect their host country's laws and regulations (Ex 23:9; Lev 19:33-34; cf. Deut 10:19-20; Ex 22:20; Rom 12). Bedford-Strohm (2008:40) argued that Christians are destined for love, and that they are commanded to love strangers among them. Because the church is destined for love and is ordered by God's Word to love strangers, it should stand against the discrimination of migrants and refugees. Bedford-Strohm (2008:40) added that Christian love towards strangers arises from the twofold coherence commandments to love God and to love thy neighbour (Matthew 22:40). The Lausanne (2004) forum added that one of God's commandments to His people is to love foreigners and strangers in the land and to treat them with respect.

While the World Council of Churches' (2014), Bedford-Strohm's (2008) and Lausanne's (2004) formulations challenge people to be hospitable, they conflate the position of states and churches. It is reductionist to assume that host nations should be compelled to act by biblical injunctions. Nations are governed by their constitutions. This lack of a clear distinction between states and churches weakens the position of churches in contributing to the migration debate. While churches are subsystems of communities and societies, they are distinct as sacred communities (Magezi 2007:176). 
Therefore, clear connections that are guided by scriptures should be drawn between churches and their communities. Stated differently, a legitimate link between churches and the rest of society must be made, rather than viewing them as not separate.

Groody (2009; 2013) developed a convincing theological framework of migration from a Systematic Theological perspective and located migration within the broader theological concern for the church. His theological premise of migration is that God, in Jesus, so loved the world that $\mathrm{He}$ migrated into the far and distant country of our broken human existence and laid down His life on a cross so that humanity could be reconciled to Him and migrate back to our homeland with God and enjoy renewed fellowship at all levels of our relationships. He maintains that, from the perspective of migration, the Christian tradition involves perceiving what God is doing in the world through Jesus Christ and understanding God's desire to cross over the various barriers that divide and alienate our relationships (Groody 2009).

Groody (2009) delineated four foundations of such a theology: the Imago Dei, crossing the problem-person divide; the Verbum Dei, crossing the divine-human divide; the Missio Dei, crossing the human-human divide; and the Visio Dei, crossing the country-Kingdom divide. These foundations give expression to the ways in which God reconciles the world to himself, break down the divisions in our relationships, and help us to understand God's movement in our world and our response to God's grace.

Groody's (2009; 2013) theology of migration places God at the centre of discussion. Theological reflection on migration should be viewed from God's perspective. This implies that migration theology, and by implication, ecclesiological discussions, has to take into consideration God's purpose and mission on earth. This challenges ecclesiological positions where churches are predominantly used for social networks - as is done by migrant churches (glocal and ethnic churches in the diaspora). At the same time, it challenges the exclusion of migrants by some host communities' churches. Groody (2013) maintained that migration is our spiritual gene. The people of God come into being through the salvation achieved because of God's migration to earth and his resultant death to redeem humanity. The implication of this theological realization is that it challenges the people of God in migrant host countries to change their mind-sets from apathy and indifference, to love and inclusion. It cultivates a hospitality and empathetic 
spirit, and challenges people to reimagine what it means to embrace other human beings. It challenges ideas of exclusivity and encourages people to identify with the migrant and view him/her as a sister and brother.

\section{Practical theological imagination of home: responsive theology for migrant care and ministry}

Cahalan and Mikoski (2014:3) argued that practical theology includes imagination. Imagination involves an array of things such as interpretation, reflection and even dreaming of alternative ideal situations in a broken world. Louw (2008:17) explained that practical theology deals with the "praxis of God as related to the praxis of faith within a vivid social, cultural and contextual encounter between God and human beings." Practical theology entails identifying God in the real world. Farley (1983:27) argued that theologia practica is simply the habitus viewed to its end (from the spiritual perspective of the ultimate). Practice entails wisdom in which the divine object sets requirements of obedience and life. Cruz (2010:121), arguing for a contextual approach to theology, advised that all theology participates in history and contributes to real life. Theology should address the issues of the day and discuss current events. Cruz's (2010:121) contention clearly indicates that theology should contribute to and participate in real life matters in a practical way, rather than only focusing on contemplation. Louw (2014) therefore referred to practical theology as 'life science' (cura vitae).

Kumlehn (2011) cited by Louw (2016) referred to practical theology as a science that should focus on promoting a kind of 'religion of life' (Religion des Lebens). This implies that there is a connection between life and religious experiences. Therefore, practical theology should engage with life issues, and should strive to enhance quality of life and focus on human well-being, health and healing. According to Korsch (2011) as cited by Louw (2016), viewing life as an object of practical theological reflection entails understanding (hermeneutics) daily life events in order to open up new options for human self-realisation. Within the context of migration, where hosts and migrants themselves are in situations of uncertainty, the question remains how practical theology can contribute to changing people's negative views of each other. How should theology, particularly practical theology, understand and interpret the current complex migration and refugee crisis in order to foster and strengthen a theology 
of compassion and overcome attitudes of apathy and indifference? The challenge is in understanding life and creating a hermeneutics of life that is connected to theology and other disciplines, such as Sociology, Psychology and Economics, tin order to explore options for dealing with the migration crisis. The World Council of Churches (2014) rightly commented that the reality of migration should challenge theology and transform the church to engage with societies meaningfully. The on-going challenge of practical theology is to develop theologies that address life issues in order to be a life science (Louw 1998, 2014). To that end, a theology of imagination of 'home away from home' should be considered. A theological framework of 'home away from home' stands in contrast to Adogame's description of migrants' 'home away from home', which entails the formation of a community that resembles the homeland and that engages in familiar activities. The theological home is an eschatological home.

\subsection{An operative theology of 'home away from home' for migrant ministry}

The Old Testament Hebrew words bayith and navah can be translated to mean home. These words may have various meanings in the Old Testament but my own interest lies within the context of the current discussion. Bayith means house, dwelling habitation, house as containing a family, those belonging to the same household, and family of descendants. Navah means to rest (as at home) or to dwell. These words share the connotation of dwelling. The Old Testament presents home as a place where someone is looked after - a place of love and care (e.g. Ruth 3:1) and where someone goes to rest after work (2 Sam 11:10), where children are taught about God's statutes (Deut 6:7), where happiness exists (Deut 24:5), where a person permanently belongs (1 Sam 7:17), where someone has to be buried (1 Samuel 25:1), where someone has permanent ownership (2 Sam 7:10), where people eat food and enjoy fellowship (Prov 7:14; $1 \mathrm{Kgs}$ 17:12), where home and land are closely linked (Num 14:30), where land and home are an inheritance (Jdg 21:24) and where you are linked to your descendants (Gen 35:27). Home is therefore an important concept in the Old Testament. A home is a place where one dwells and is a permanent inheritance where acceptance, love and security are found. It is imperative for an individual to have a home. A home makes us fully human and defines our identity, security, belonging and humanity. 
Groody (2009) advised that located within Old Testament theology, land and home are intertwined and provide an important spiritual understanding that should shape human beings' view of land. Gen $12 ; 17: 7-8$ presented the land promise for Israel, which is an important part of the promise with Abraham. The land promise has implications for Christians for at least three reasons.

Firstly, it has a wider setting within the background of the Old Testament, that is Gen 1-11 and the way the promise can never be fulfilled by Canaan but which points to a superseding promise of the new creation. Secondly, there is deep insight into the spiritual dimension of the promise since it is part of the purpose that God has elected people to live before him. Thirdly, there is a prophetic vision that connects the new covenant and the restored land. Therefore, to limit the promise of the Promised Land to Israel is to deny the New Testament's affirmation that Christians are the heirs of the Abrahamic promises (Rom 4:13, Gal 3:16, 29). It is clear that the Old Testament's spiritual dimension of land points us to our original home, the Garden of Eden. This reiteration of Eden embraces all humanity as pilgrims who are moving or migrating to their original home. The promise of land in the prophetic vision of Ezekiel 36:25-28 7 and Jeremiah 31:23-40 also underscores this reality.

In the New Testament, the Greek word oikos means home. This word can also be translated to mean an inhabited house, any building, or dwelling place, or the place where one has fixed his house or family. An analysis of the New Testament reveals home as a permanent place of dwelling, in which one experiences acceptance and generosity, and is a place in which family members dwell together as members of the same household. Home is tied to the concept of family. More importantly, a home is a place of unconditional love, forgiveness and security (Matt 9:6; cf. Mk 2:1, 2:11, 5:19, 7:30, 8:26, 10:29; Lk 1:56, 15:30, 18:29; Jn 16:32, 19:27; Acts 7:20, 21:16; 1 Cor 11:34).

The spiritual dimension of the New Testament's meaning of home is connected to Jesus Christ (Phil 3:12-21, especially 3:14b). Christians' citizenship and dwelling is in heaven (eschatological being through pneumatology). The concept of a permanent home in heaven is made implicit by referring to Christians as aliens or strangers (1 Pet 2:11-12, cf. Heb 11:1316). Jesus Himself refers to Christians as not of this world (Jn 17:16; In 15:1819). This suggests that people's views of their earthly home as a permanent 
dwelling place are myopic, and point to a limited understanding of the nature and extent of the biblical meaning of home. A permanent dimension of our earthly home should be understood in the context of the limited time that we dwell on the earth. Jesus explicitly referred to a permanent home when comforting his disciples and saying He was going to heaven (His place of eternal dwelling) to prepare a place for them (Jn 14:1). Jesus' disciples are not permanent citizens of this world, instead they should look forward to a time when He will come back to take them to their eternal home (Jn 14:3), where they will live in God's dwelling place in the new heaven and the new earth and be with their God ( $\operatorname{Rev} 21: 3)$. The heavenly home is not just a spiritual reality; it is a physical place where the people of God will dwell with Him. Jesus speaks of many houses in His Father's place where He will prepare more places for believers to dwell (Jn 14:1-4).

The above outline of humanity's spiritual dimension of home has some important implications for the way people view their homes and churches in a host or foreign land. It calls for a new way of thinking, which should influence the churches in their conduct. In essence, the host people's nation is not their home, just as it is not the refugees' or migrants' home. Hosting individuals who provide hospitality should be conscious that they are a stranger hosting a stranger on their migration journey to a real home. In this sense, a theological homo viator, as an ecclesiological model that responds to migration challenges, is critical. A homo viator is a pilgrim, a man on his journey to finding God. This should challenge and help people to reimagine what it means to be a stranger, away from home and waiting to be permanently home. Therefore, host nations and migrants are caught in the same migratory situation. Marcel (2009) pointed out that every human being should be aware of the transcendent being beyond this world. Therefore, there should be no exclusion since all people are on a pilgrimage. This calls people everywhere to embrace each other regardless of their status (citizen or non-citizens). Louw (2016) called for a compassion motif as an empowering category in the way the (Christians) citizens of a country view the foreigners in their nation. However, this motif should not be a private reality for Christians, but a lived reality that provides a model for how to live in a global world. The church should integrate the model of migrants and host churches. This challenges 'glocal' and host country churches. In view of the above, the question that arises is: How does one proceed from a theoretical reflection to a practical dimension and 
intervention for a ministerial formation that is informed by the theological notion of eschatological home?

\subsection{A diagnostic chart for responses to migration}

Louw $(1998,2016)$ explained that a pastoral diagnosis chart is not about classification, but rather about a hermeneutical understanding of how life issues are linked and interconnected. The development of a diagnostic chart is based on the presupposition that insight into the systemic networking of attitudes and paradigms helps individuals to consider different strategic options, especially when one has to link the options to basic theological categories. Louw (2016) maintained that seeing the bigger picture brings about a kind of soberness and realism, and opens up options that create a sense of 'hope'. A diagnostic chart helps one to see the bigger picture, the networking dynamics of life as an existential and qualitative category. Within this framework, life is a web where the dynamics and structural interplay between various situations, experiences and relationships should be understood as part of a reality within the global village. Complexity is the norm. One has to contend with complexity and explore options to cope within the situation meaningfully. This is what Korsch (2011:34) as cited by Louw (2016) meant by 'exploring new categories' ("Spuren des Selbstausdrucks und Wetaneignung").

The diagnostic model has four (4) positions (called zones) in which both migrants and host individuals are located (figure 1 below). An individual cannot be caged into one zone, but moves between zones. Zone A (Victim zone) represents a displaced individual who is a resident in a host country. Zone B (Complacency zone) represents individuals in migrant countries. Zone C (Wishful zone) represents the unrealistic wishful mind-set of migrants in a host country. Zone D (Eschatological home zone) represents a constructive mind-set for migrants and host nation individuals (and communities). At any given point, an individual could locate him/herself within the zones to map out their thinking and actions.

Arrow 1 represents migrants who oscillate between zones A and C. It represents being trapped - where the reality of the situation in a host country results in wishful thinking (i.e. I wish I were in my home country). Arrow 2 shows wishful thinking of migrants who want to have the same rights as host people (in zone B) (i.e. I wish I were a citizen of the host country). At the same time, the arrow represents individuals in host countries who look 
down on migrants and view themselves as better and superior. Arrow 3 shows the recommended direction of movement by migrants (zone $\mathrm{A}$ and B) and host nation individuals (zone B) to zone D.

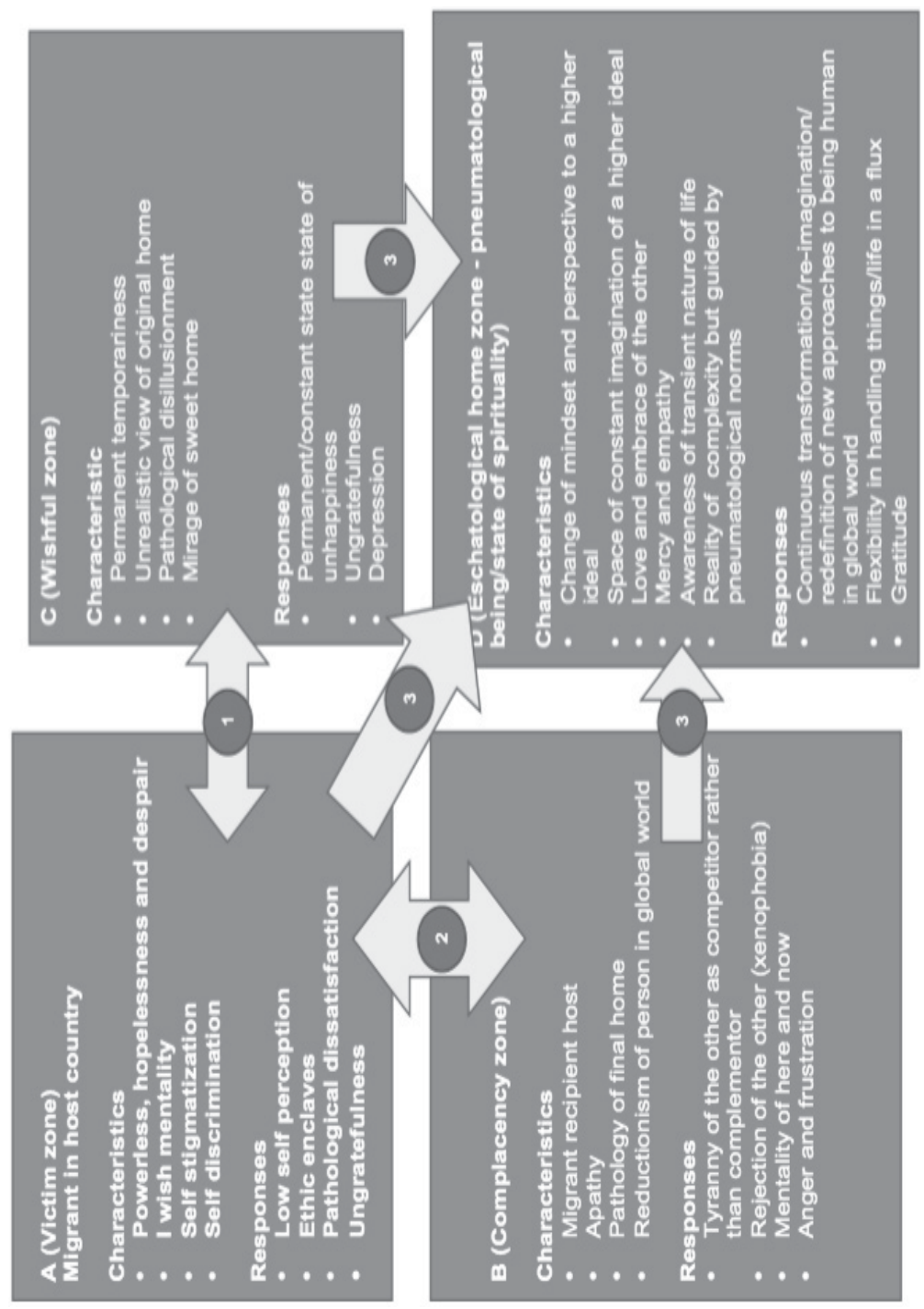

Figure 1: Hermeneutics of migration attitude change within a practical theologicalimagination of home 
The advantage of using a graphic design is that it highlights different positions and shows how they relate to each other. It also widens one's perspective and demonstrates the complexity of the migration crisis. Seeing the bigger picture raises awareness on the complexities of the situation, and shows that an 'either-or' approach is inappropriate. As Louw (2016) noted, the complexity of a paradox is about a zigzag spiral of networking. Due to systemic interconnectedness and networking dynamics, caregivers, social helpers or politicians, as well as refugees and even perpetrators (some migrants), should be understood within their own dynamic positioning in the complexity of the migration crisis. Orientation and disorientation are simultaneously at stake. Therefore, reorientation and re-imagination should be the eventual outcome of applying the diagnostic chart. An awareness of the complexity of systemic positioning and repositioning creates the ability to see life within the migration situation differently. Positive, constructive responses entail change and insight into the different intentions that inform repositioning across the zones.

Zone A designates migrants as victims of displacement (from countries of origin) and victims of exclusion (in host countries), who feel powerless, hopeless and despair. In addition to exclusion by host communities, they self-exclude and self-discriminate. This gives rise to ethnic enclaves and glocal churches as social networking spaces (Adogame 2013). Because of their self-excluding nature, these networks fan low self-perception, ungratefulness and create pathological dissatisfaction due the failure to realize the benefits of being in a host country.

Zone B represents some individuals and communities in host countries who view their country as a heaven on earth. They demonstrate a diminished view of what it means to live in a global village, have an inward focus and a life characterized by complacency. They view migrants as competitors who should be resisted and who will deplete resources. Individuals in Zone B have a 'here-and-now' mind-set, reject migrants and develop xenophobic tendencies. Migrants trigger anger and frustration. In this zone, national pride and love for one's country leads to overprotection and the exclusion migrants.

Zone $\mathrm{C}$ represents the 'in between' mind-set among migrants who wish that they were in their homeland, despite people in their home country wishing that they could migrate. The wishful-thinking in this zone results 
in an on-going state of temporariness, even when migrants are granted full citizenship. They maintain an unrealistic view of their original home, are disillusioned and do not realise that it does not exist anymore, either because of war, conflict or economic turmoil. They sometimes find themselves in a perpetual state of unhappiness, ungratefulness and depression and consequently fail to cope in a foreign land.

Zone $\mathrm{D}$ represents a progressive and constructive mind-set that emerges from a pneumatological state of being, a state of spirituality where home is both a state of being (realized eschatology) and an anticipated 'still to come' home (unrealized eschatology). The actual home and citizenship (Philippians 3:20) are places of dwelling with Christ (John 14:1-4) in heaven (Revelation 21:3). However, home is here now by virtue of union with Christ (realized eschatology) and not necessarily geographical and in the future. In this sense, both a host country's people and migrants are strangers on a journey of migration to a real home (unrealized eschatology), they are homo viator, pilgrims on their way to a final home. This challenges individuals to be continually transform and reimagine what it means to live in a global village. It helps people to redefine and explore new approaches to being human. It makes one contend with complexity and options.

Zone $\mathrm{D}$ enables one to be flexible in handling life in a flux, where, like migrants, people find themselves in transitional situations. The realization that humans are homo viator evokes gratitude in a person. Appreciating the provisions of a host country arouses gratitude in migrants, while host countries' citizens are grateful for the peace enjoyed in the country. Louw (2016) rightly stated that this calls for a compassion motif in how the citizens of a country view the migrants in their nation. This should result in mercy, empathy, love and an embracing of other people (Bedford-Strohm 2008; Lausanne 2004). Operating in zone D leads to the establishment of contextual churches (operative ecclesiology), and challenges migrants to shift from glocal churches and enclave communities to integrated churches. Similarly, exclusive churches in host communities are challenged to integrate migrants. Operative ecclesiology entails establishing churches that respond to the concrete contexts of people's lives - including migration. This transcends narrow denominational traditions and dogmatic confessions to respond to communal life systems. This way theology imparts life and wellbeing, and becomes a life science. It makes 
people face practical challenges by drawing on theological tools to develop new imaginations and explore options to cope with the complex world. The migration crisis is a challenge that requires such a functional theology.

\section{Conclusion}

This article considered the complex issue of migration. It discussed the challenges associated with migration from the perspectives of migrants and host nations. It highlighted the dilemmas posed by migration, and located migration within a theological perspective by discussing the responsive mechanisms employed by host country churches and migrant churches. A migration responsive model, that challenges host country churches and migrant glocal churches, was proposed. The model employs a practical theological imagination of home as a responsive theology for migrant care and ministry.

\section{References}

Adogame, Afe 2013.

Albuja, Sebastián 2014. Criminal violence and displacement in Mexico.

[Online]. Available: http://www.fmreview.org/crisis/albuja.html [Accessed: 25 May 2016].

Bedford-Strohm, Heinrich 2008. 'Responding to the Challenges of Migration and Flight from a Perspective of Theological Ethics.' In Theological Reflections on Migration. Online: Available: http://www. ccme.be/fileadmin/filer/ccme/01_WHO_WE_ARE/2008_CCME_Reader-_Theological_ Reflections_on_Migration.pdf [Accessed: 20 May 2016].

Bergson, E 2015. Catholicity Challenging Ethnicity. An Ecclesiological Study of Churches in Post-apartheid South Africa. Uppsala: Uppsala University.

Bose, Sahana 2014. 'Illegal Migration in the Indian Sunderbans.' In Forced Migration review. Issue 45. [Online] Available: http://connection.ebscohost. com/c/articles/94903338/illegal-migration-indian-sunderbans [Accessed: 30 March 2016. 
Cahalan, K.A. and Mikoski, G.S. 2014. (eds). Opening the Field of Practical Theology. New York: Rowan and Littlefield.

Castles, S. and Miller, M.J. 2009. The Age of Migration. International Population Movements in the Modern World. London: Castillo Guerra.

Chelius, L.C. 2014. Mexicans seeking political asylum. [Online] Available: http://www.fmreview.org/crisis/calderon.html [Accessed: 28 May 2016].

Cruz, Gemma, Tulud. 2010. An Intercultural Theology of Migration. Boston: Brill.

Datta Kavita, McIlwaine Cathy, Evans Yara, Herbert Joanna, May Jon and Willis Jane. 2006. Work and survival strategies among low-paid migrants in London. Department of Geography Queen Mary. London: University of London.

Faulconbridge, G. and Young, S. 2015. World unites on Paris, Beirut. Cape Times, November 16, 2015.

Gannon John C. 2001. Growing global migration and its implications for the United States. [Online] Available: https://fas.org/irp/nic/migration [Accessed: 25 May 2016].

Garson, J. P. and Loizillon, A. 2003. The economic and social aspects of migration- OECD. [Online] Available: www.oecd.org/migration/ mig/15516948.pdf [Accessed on 18 May 2016].

Gilmore Kate. 2016. Keynote address: Side event "Migrants in transit" by Deputy High Commissioner for Human Rights. [Online] Available: http://www.ohchr.org [Accessed: 20 May 2016].

Groody, D.G. 2009. Crossing the divide: foundations of a theology of migration and refugees. Washington: Rowman \& Littlefield.

Groody, D.G. 2013. The Church on the move: mission in age of migration. Mission Studies 30(1): 27-42.

Hastings Borough Council. 2015. What are the specific problems migrants face? [Online]. Available: http://www.hastings.gov.uk/housing_tax_benefits/ housing_options/migrant_housing_toolkit/specific_migrant_problems/ [Accessed: 20 May 2016]. 
Hirschman. Charles. 2003. The Role of Religion in the Origins and Adaptation of Immigrant Groups in the United States. Revision of a paper presented at the conference on "Conceptual and Methodological Developments in the Study of International Migration” at Princeton University, May 23-25, 2003.

Human Rights Watch. 2015. World Report 2015: Kenya - Events of 2014. [Online] Available: https://www.hrw.org/world-report/2015/country-chapters/ kenya [Accessed: 20 May 2016].

International Organisation for Migration (IOM). 2014. Global Migration Trends: an overview. [Online] Available: http://missingmigrants.iom.int/sites/ default/files/documents/Global_Migration_Trends_PDF_FinalVH_with\%20References. pdf [Accessed: 28 May 2016].

Karakas, Cemal. 2015. Economic challenges and prospects of the refugee influx, Briefing of December 2015 - European Parliamentary Research Service. [Online] Available: http://www.europarl.europa.eu/ RegData/etudes/BRIE/2015/572809/EPRS_BRI(2015)572809_EN.pdf [Accessed: 10 May 2016].

Lausanne Occasional Paper no. 55. 2004. The new people next door. [Online] Available: http://www.lausanne.org [Accessed: 20 May 2016].

Louw, D.J. 1998. A pastoral hermeneutics of care and encounter. Cape Town: Lux Verbi.

Louw D.J. 2008. Cura Vitae: Illness and the Healing of Life in Pastoral Care and Counselling. Cape Town: Lux Verbi.

Louw, D.J. 2014, Wholeness in hope care on nurturing the beauty of the Human soul in spiritual healing. Wien LIT.

Louw, D.J. 2016. Between xenophobia and xenodochia in an operative ecclesiology of home: the plight of refugees and migrants as challenge to a diagnostic approach in a pastoral hermeneutics of caregiving. Unpublished paper.

Magezi, V 2007. HIV and AIDS, Poverty and Pastoral Care \& Counselling: a home-based and congregational systems ministerial approach in Africa. Stellenbosch: Sun Media. 
Marcel, Gabriel 2009. Homo Viator: Introduction to a Metaphysic of Hope. Indiana: St. Augustine's Press.

Martin, Philip 2013. 'The Global Challenge of Managing Migration.' Population Bulletin 68, no. 2 (2013).

Martin, Susan F., Weerasinghe Sanjula and Taylor Abbie. 2015. "Humanitarian Crises and Migration: Causes, Consequences and Responses”, Journal of Refugee Studies (2015) 28 (1): 138-140.

McAdam, Jane. 2014. 'The concept of crisis migration.' In Forced migration review. Issue 45, 2014.

Metcalfe-Hough, V 2015. A migration Crisis? Facts, challenges and possible solutions. [Online] Available: https://www.odi.org/sites/odi.org.uk/ files/odi-assets/publications...files/9913.pdf [Accessed: 30 April 2016].

Nie, Z 2015. The global edge: The effects on host countries. [Online] Available: http://globaledge.msu.edu/blog/post/30996/the-effects-of-refugees-onhost-countries [Accessed: 5 May 2016].

Nuñez, C 2014. The 7 biggest challenges facing refugees and immigrants in the US. [Online] Available: https://www.globalcitizen.org/en/content/the-7biggest-challenges-facing-refugees-and-immig/ [Accessed: 30 March 2016].

Oluoch, Vick 2012. Racism and other problems that immigrants face in the United States. [Online] Available: https://vickoluoch.wordpress. com/2012/12/17/racism-and-other-problems-that-immigrants-face-in-the-united-states/ [Accessed: 31 May 2016].

Pakoz, Ziya Muhammed 2016. Refugee haven under attack. Mail and Guardian 20-26 May, 2016.

Plucinska, Joanna 2015. The Paris Attacks Have Put Europe's Refugee Crisis under Renewed Scrutiny. [Online]. Avaiolable: http://time.com/ author/joanna-plucinska/ [Accessed: 28 May 2016].

Polak, R 2014. "Migration als Ort der Theologie“. In: T. Kessler (ed.) Migration als Ort der Theologie. Regensburg: Verlag Friedrich Pustet, pp. 1-20. 
Richard, A.C. 2014. The Syrian Refugee Crisis - U.S. Department of State. [Online] Avaiolable: www.state.gov/j/prm//releases/remarks/2014/219388.httm [Accessed: 23 May 2016].

Robertson, Roland. 1992. Globalization: Social Theory and Global Culture. London: Sage.

Schär, Benz H.R and Geisler Ralf, 2008. A Churches Commission for Migrants in Europe Reader, Brussels. [Online] Available: http://www. ccme.be/fileadmin/filer/ccme/01_WHO_WE_ARE/2008_CCME_Reader-_Theological_ Reflections_on_Migration.pdf [Accessed: 20 May 2016].

Skeldon, Ronald 2013. "Global Migration: Demographic Aspects and Its Relevance for Development. Technical paper, No. 2013/6”. In United Nations Department of Economic and Social Affairs.

Statistics Canada 2005. [Online] Available: http://www.statcan.gc.ca/pub/11-008x/2007000/c-g/4097864-eng.htm [Accessed: 31 January 2016].

Sutherland, Peter D 2014. “Foreword on migrants in crisis”. In Forced migration review. Issue 45, 2014.

Swyngedouw, Erik 2004. “Globalisation or 'Glocalisation'? Networks, Territories and Rescaling." Cambridge Review of International Affairs, 17(1): $25-48$.

Tan, Jonathan. Y 2012. Migration in Asian and its missiological implications: insights from the migration theology of the Federations of Asian Bishops' conference (FABC), Mission Studies, 29(1), pp. 45-61.

Thomas, Fiona C 2010. Migration Studies Unit Working Papers. [Online] Available: http://www.Ise.ac.uk/government/research/resgroups/MSU/documents/ workingPapers/WP_2010_01.pdf [Accessed: 28 May 2016].

Thomsen, P.M. 2016. The refugee surge in Europe: Economic challenges. [Online] Available: https://www.imf.org/external/pubs/ft/sdn/2016/sdn1602.pdf [Accessed: 15 May 2016]. 
United Nations, Department of Economic and Social Affairs, Population Division. 2013. World Migration in Figures: A joint contribution by UN-DESA and the OECD to the United Nations High-Level Dialogue on Migration and Development, 3-4 October 2013.

United Nations Human Rights Commission (UNHRC). 2015. Migration, human rights and governance. Hand Book for parliamentarians no 24. Published by Inter-Parliamentary Union 2015.

Vick, K 2015. Angela Merkel. Chancellor of the Free World. In: Time, vol. 186 , no. 25-26, pp. 26-51.

Walt, V 2015. "World. An attack Foretold”. In Time, January 19, pp. 8-9.

Willems, R 2005. "Coping with displacement: Social networking among urban refugees in an east African context". In I. Ohta \& Y.D. Gebre (Eds), Displacement risks in Africa: Refugees, resettlers and their host populations, pp. 53-77. Melbourne: Trans Pacific Press.

World Council of Churches. 2014. Migration transforms how churches do theology. [Online] Available: http://www.oikoumene.org/en/what-we-do/ migration-and-social-justice [Accessed: 10 April 2016]. 